\author{
М. Э. Рут \\ Уральский федеральный университет \\ Екатеринбург, Россия \\ moerut@yandex.ru
}

\title{
Об ономастике и диалектной лексикографии (из опыта работы над дополнениями к «Словарю говоров Русского Севера»)*
}

Для лексикографов-диалектологов всегда стоит вопрос о целесообразности включения в диалектный словарь ономастических данных: индивидуальных и коллективных прозвищ, хрононимов, астронимов, топонимов. Аргументом «за» является отражение в региональной ономастике диалектных слов, часть из которых сохранилась только в составе данного онима. Аргументом «против» служит развитие собственно ономастической лексикографии, где имена собственные должны занять свое место и получить все необходимые комментарии.

В разные периоды существования диалектной лексикографии и для разных классов собственных имен вопрос решался по-разному: составители дореволюционных словарей тяготели к включению собственных имен в словарные статьи, словари советского периода, как правило, от них отказывались. Прозвища включаются в диалектные словари чаще, чем топонимы. Достаточно часто в словарях присутствуют хрононимы, однако, скорее всего, потому, что их статус как имен собственных не является общепризнанным. Астронимы фиксируются достаточно редко, но это объясняется раритетностью самого материала в современных русских говорах.

Вопрос о включении собственных имен стоял в свое время и перед составителями «Словаря говоров Русского Севера» [СГРС]. Вступительная статья к первому тому словаря обходит этот вопрос молчанием, однако в корпусе этого тома имена собственные отсутствуют, хотя местные топонимы, личные имена, оттопонимические прилагательные, входящие в состав устойчивых выражений, представлены достаточно широко.

\footnotetext{
* Исследование проводится при поддержке гранта РФФИ № 18-012-00385 «Словарь говоров Русского Севера: дополнительные материалы».

(C) Рут М. Э., 2019
} 
В последующих томах отмечается достаточно последовательное включение хрононимов. Этому нарушению заданного принципа есть ряд объяснений: во-первых, методики полевого сбора диалектной лексики Топонимической экспедиции Уральского университета в последние десятилетия приобрели ярко выраженную этнолингвистическую направленность, и сведения о знаменательных датах народного календаря естественно вписываются в общий контекст собирательских бесед; во-вторых, народные хрононимы часто представляют собой местную переработку общеизвестного хрононима, отражают фонетические и словообразовательные черты местного диалекта; наконец, в говорах нередки факты апеллятивизации хрононимов, возникновение отхрононимических образований различной семантики.

Работая над томом дополнений к словарю, составители находятся в ситуации принятия решения: включать или не включать хрононимы. С одной стороны, вышел полный словарь хрононимов [РНК], где исчерпывающе представлены материалы полевых сборов на территории Русского Севера. С другой стороны, в основной корпус на $A-M$ многие хрононимы уже включены, они есть и в черновых материалах дополнений (полевые сборы последних двух десятилетий), в том числе с географией, ранее не отраженной.

Докладчик надеется на обсуждение вопроса, какое из двух предложенных решений стоит выбрать.

РНК - Атрошенко О. В., Кривощапова Ю. А., Осипова К. В. Русский народный календарь : этнолингв. словарь / под ред. Е. Л. Березович. М., 2015.

СГРС - Словарь говоров Русского Севера / под ред. А. К. Матвеева. Екатеринбург, 2001-. Т. 1-. 